\title{
An Investigation Of University Students' Metaphoric Perceptions Of Musician And Artist Concepts*
}

\section{Research Article}

Bahar AYDIN ${ }^{1}$

${ }^{1}$ Dokuz Eylül University, Faculty of Fine Arts, Department of Musicology, İzmir, Turkey, ORCID: 0000-0002-2392-8317

To cite this article: Aydin, B. (2021). An investigation of university students' metaphoric perceptions of musician and artist concepts, International Online Journal of Educational Sciences, 13(1), 65-85.

\begin{abstract}
ARTICLE INFO
Article History:

Received: 10.03.2020

Available online:

06.02.2021

ABSTRACT

Metaphors play a cognitive and affective role in how people think and perceive a situation, an event or a person. The study of metaphors is one of the methods used to evaluate the conceptual meaning of individuals' beliefs and perceptions. This study aimed to understand how" the musician" and "the artist" concepts, which are often used as close meanings or synonyms, are misused and perceived by university students whose professional education is not music. A total of 110 students from various departments of Dokuz Eylül University voluntarily participated in the study in the 2018-2019 academic year. The study was descriptive and it was qualitative. Phenomenology design was adopted in the study and the data were analyzed by the content analysis technique. The data were analyzed in the Nvivo qualitative data analysis software and categorized according to the experts' opinions. According to the results of the research, 62 metaphors related to "the artist" concept and 65 metaphors related to "the musician" concept were used. According to the metaphors, 9 categories related to the concept of "the artist, and 7 categories related to the concept of "the musician" were formed. Examining the categories formed, it was seen that "creative", "relaxing" and "unifying" were the common categories for both the artist and the musician. The other prominent categories for the artist concept included "enlightener" and "freedom" while the other prominent categories for the musician concept included expression of "abstractness", "educator-instructor" and "value".
\end{abstract}

C 2021 IOJES. All rights reserved

Keywords:

Metaphor, musician, artist, concept, perception.

\section{Introduction}

Music has a structure that is intertwined with culture as in other art branches and has played an important role in every society throughout history. Concepts of art and artist and perceptions about playing music and the concept of musician are shaped according to the cultural perception of the group or community

\footnotetext{
* This article was presented as an oral presentation at the 1st International Sanad Congress

${ }^{1}$ Corresponding author's address: Dokuz Eylül Üniversitesi Güzel Sanatlar Fakültesi Müzik Bilimleri Bölümü

Telephone: +905317917052

e-mail: bahar.aydin@deu.edu.tr

DOI: https://doi.org/10.15345/iojes.2021.01.005
} 
that defines them, beyond their dictionary meaning. "Musician" is used for people who perform music in various ways. The musician is defined in the Turkish Language Association as "someone who creates, composes or plays musical works". "Artist" is defined as a someone "who has creativity and creates pieces of art in any field of fine arts (such as theater, painting, music)", and in the Turkish dictionary of science terms, "artist" is defined as someone who has a special talent in performing in an art branch in which the creative action depends on aesthetic evaluation, imagination and authenticity, someone who creates a work of art, plays in created works of art, interprets and applies them (TDK, 2020).

Different from the lexical meanings, the meanings attributed to the concepts of artist and musician may differ. For example, out of two people who produced the same product, are both artists? Are both musicians? Or is one a musician and the other an artist? Based on these questions, "What is art?", "Who is called an artist?" are among the questions that have been asked for centuries and are still being answered today. It is also observed that there is a common ambiguity in this regard. When considered in the context of the meaning of the word, it is seen that two definitions as artist or musician may be appropriate for the person performing the art of music. However, in reality, the meanings attributed to these concepts can be shaped under the influence of some internal and external factors. Tezcan $(2018 ; 40)$ expressed that social institutions such as family, economy, politics, religion, and education are directly or indirectly related to the concept of art and artist, and the rules and value judgments of social life -for example, who would be an artist, how to be an artist, what kind of works would be produced- are determined by these social institutions. For example, while the meanings attributed to the concepts of musician and artist by a person who continues a profession related to music is different, it may be different in another profession. Similarly, it may differ for a university student studying in the arts or music department and a student in the physics or mathematics department. However, it is thought that individuals studying at universities, whether in a department related to art or a non-art field, should have a certain level of cultural perception and knowledge. Doğan (2020:195) stated that individuals in developed countries are now expected not only to have professional knowledge but also to be intellectually equipped.

Scott (2002) states that universities play an important role in the scientific, economic, technological, social, and cultural developments of societies and that they provide a transition between social layers as a dynamic institution that provides scientific and technical knowledge and professional skills in order to improve the quality of social and individual life (as cited in Sahin, Zoraloglu \& Frrat, 2011). In this context, it is important to understand the perceptions of the students who study in the fields other than music and art, and even those that are not very close to art, about the concept of artist and musician, to be able to read the meanings they attribute to art, to understand what music means to them and how the musician and the artist are perceived in this framework. It is also important in terms of giving an idea about the mission of artists and musicians to share art and music with various layers of society.

Definitions of the concepts about music and art and the concepts of artist and musician by a community can be influential in determining the future direction of a certain section of society as well as being influenced by the conditions and experiences of that society section. In the studies on the concepts of art and artist, the features of eye-opening, guiding, illuminating, creative, original and innovative (Yalcin Wells, 2015, Hiçyllmaz and Adanır, 2019; Akdeniz and Çarıkçı, 2017; Yalcin Wells, 2015; Kalyoncu, 2013) showed that the artist is perceived as the pioneer of changes and developments with an innovative and original approach as well as with the creative characteristics. Novak-Leonard and Skaggs (2017) discussed the changes in the artistic and cultural field through the roles of the artists in the society and defined the artists as the entrepreneurs of civil thought and social changes.

Understanding art and music related perceptions as a reflection of culture is important in terms of understanding similar or different cultural features. Videira $(2011 ; 255)$ stated that all linguistic structures are 
culturally related and may differ according to the society and the effects that make up the perception and definition of music are composed of traditions, rules, order and human experiences within that community rather than the music itself. When Txakartegi and Gomez (2008) searched answers to issues, like professional expectations of music students with different cultural backgrounds and involved in various music activities outside the school, what kind of music they like, subjects that they think to be useful in music-related lessons at school, and the musical activities they take outside the school, in their study, they associate their data with cultural elements that include common aspects and differences.

Understanding the perceptions of individuals with regard to the concepts of artists and musicians with their similar and unlike aspects is important in terms of a more detailed and in-depth study of the structures of thought about these concepts beyond their dictionary meanings. While humankind lives with the beings in nature, it sometimes imitates them and sometimes tries to express itself by establishing a relationship between its own life and those beings. Metaphors constitute one of these expressing forms (Aydin and Pehlivan, 2010). Metaphors are an important data collection tool in understanding thought structures and understanding and making sense of perceptions. Uygun (2015); Cimen and Ozevin (2019) stated that metaphors are powerful tools of expression that allow individuals to explain their perceptions of abstract concepts by replacing them with concrete concepts, while Goldstein (2005) stated that metaphors redefines facts and encourages reconceptualization of the problem situations as they affect the way we perceive situations and events (as cited in Cerit 2008; 604).

The ability to understand and make sense of perceptions allows us to understand not only the instant thoughts of metaphors about an event, situation or profession group, but also the thoughts about what the idealized subject should be. While the data obtained from the participants define the concepts of "artist" and "musician", they also give clues about their thoughts about how they can become musicians or artists at the same time. For example, features such as authentic, guiding or expressing peace defined in various studies may also express the effect expected from the artist and musician. In their study, Saban, Kocbeker, and Saban (2007) exemplified this situation with the phrase "a graduate student of guidance and psychological counseling department is similar to a gardener" and defined her/his cultivating, caring, growing and beautifying features as well as how a guide teacher should be through the metaphor. In this context, the study also tries to understand the perceptions of pre-service teachers in the study group of the study about the concept of artist and musician. Because perceptions formed by past experiences are transferred to the education process directly or indirectly. Pehlivan et al. (2019) state that pre-service teachers have experienced various experiences both during their time in teacher training programs and in their previous lives, and that they are involved in the process of shaping education.

As a result, it is possible to say that metaphors help us understand the some values by explaining the perceptions about cultural elements through language and have strong cultural and social effects in making sense of the concepts. In addition to this, metaphors provide different and similar features of a situation, allowing comparison and handling of the subject in more detail. Girmen (2007; as cited in 2018; 20) stated that metaphor always has further, more intense meaning value than its real meaning, has relative value, but also contains clues in recognizing culture and character by carrying social meaning values.

The study was carried out with students who are not professionally musicians or artists and do not receive education in music or art departments. The reason for this is that the perceptions of a working group who continue their education in different departments and have completed their formal education would better reflect the perception of the university students. The perceptions of musicians and non-musicians about the concepts of music and art, and hence the definitions of musicians and artists also differ. Schaerlaken et al. (2019) stated that musical experiences are effective in the perception and conceptualization of music and that there are differences between people who are musicians and not. In addition to this, it is seen that there is a 
great variety of meanings and interchangeability in the use of these concepts. While the definition of perceived characteristics for art, artist, music and musician is influenced by individual perceptions and cultural characteristics, perceptions of individuals who are/are not musicians or artists further diversify the definitions.

\subsection{Related literature}

Although there is no direct study on the concept of musician in the literature, various studies on "music" and "music education" are encountered. It is seen in the related literature that perceptions about music show similar features to the concept of musician. Regarding the metaphors that musicians and non-musicians use about music, Schaerlaken et al. (2019) examined how the listener uses metaphors in music, how s/he conceptualizes music and how the musical meaning emerges. In this context, metaphors used by individuals who are/n't musicians based on their musical experiences and perceptions were collected through concerts and data were collected under categories of flow, movement, power, interior and strolling. In his study, Antovic (2014) discussed the metaphorization of music, and studies conceptualization, internal and external metaphors, and subjects like metaphor problem in music. In the other part of his work, he works with participants who speak different mother tongue, show different cognitive characteristics and have different musical qualifications and draws attention to the cultural power of metaphors in music, arguing that there are similarities as well as differences in the categorization of the data obtained.

It is seen that metaphors are used not only in making sense of the concepts related to music, but also in various dimensions of music education. In his study, Wolfe (2019) stated that while studying music performances in the education of music students, things are transferred through metaphors and metaphors are often utilized, and in this context, metaphors play an important role in advanced activities such as perception, performance and teaching of music. In his study, he also states that the use of the correct metaphor establishes a connection between music education and learning and contributes to learning. There are also studies showing that the use of music-based metaphor contributes to learning-teaching environments and the development of positive behaviors. Uygun (2015) examined the perceptions of prospective teachers studying in different departments, including art education departments, about Turkish Folk Music and traditional Turkish Art Music through metaphors. While the data obtained from the participants are categorized, it was seen that the most used metaphors for Turkish Folk are cultural, maintaining continuity, descriptive, forming sense of belonging and a basic element; on the other hand, the most used metaphors for traditional Turkish Art music are peace, giving happiness and health, reminiscent of the past, valuable, and defining artistic features.

Ipolitoa and Adlerb (2018) discussed the effect of using a music-based metaphor and pedagogical approach on learning, teaching and conflict resolution. In the study, it is aimed to understand whether the use of music-based metaphor is effective in replacing the behaviors in negative, conflicting and highly competitive environments with more positive and cooperative behaviors or how they affect this change. The results show that participants who were not musicians but had a learning environment with musical metaphors developed further cognitively, affectively and behaviorally than their colleagues who did not use music-based metaphors.

Considering the sources related to the subject, it is seen that there are few studies on the concept of "artist", while some studies on "art" and "art education" have been carried out. Yalcin Wells (2015) conducted his study with university students studying in the department of art education and stated that the students highlighted the aspects of the "artist" like enlightening and guiding, reflective, creative, expressing freedom, authenticity and difference. One of the prominent aspects of the study is that it was conducted with students who had art education. Yalcin Wells (2015) handled her study through the perceptions of prospective teacher candidates on the concept of "teacher" and "artist" as students studying in the department of art education. Novak-Leonard and Skaggs (2017) discussed the results of their work on the perception of artists in society on 
a sociological scale, and stated that artists are determinant in the tendencies of individuals towards art and that the indicators related to the perceptions of the society towards the artist also determine the art policies in the society.

For the evaluation of art and artist through cultural perceptions, Rahman et al. (2018) evaluated art education with high school students coming from different cultural infrastructures through material, method and teacher experiences and emphasized that an art education restructured with multicultural understanding is important in terms of coexistence and socialization of different cultures.

\subsection{Aim of the Study}

In the research, it is aimed to understand the perceptions of a group of university students who are not from music and art departments, on the concepts of "musician" and "artist". Concerning the use of two concepts in daily life, it is seen that there is a similarity, diversity and confusion about who is an artist and who is a musician. Accordingly, it is aimed to understand the musicianship in a community or the perceptions of a community about the musicianship and the artist concept with different and similar aspects, and for this, it is aimed to evaluate the metaphors used for concepts by a group of university students studying in departments other than music and art departments assuming that they reflect the sections of the society, excluding artists and musicians.

In the study, an answer was sought for the question: "What are the metaphors that university students use for the concepts of 'Musician' and 'Artist' to examine their metaphorical perceptions of the concept of musician and artist?" Accordingly, the following questions have been evaluated:

1. What are the metaphors used by university students for the concepts of "musician" and "artist"?

2. Under which categories can the metaphors, used by university students regarding the concepts of "musician" and "artist", be collected?

\section{Method}

In this section, research model, study group, data collection tools and data analysis are included.

\section{Research Model}

Phenomenology pattern, one of the qualitative research methods, was used to determine the perceptions and perspectives of university students towards the concept of musician and artist. In the evaluation of the data, content analysis technique was used.

Phenomenology pattern focuses on phenomena that we are aware of but we do not have in-depth and detailed understanding of. In the world we live in, phenomena can be seen in various forms such as events, experiences, perceptions, orientations, concepts and situations. Phenomenology studies generally aim to reveal and interpret individual perceptions of a phenomenon (Yıldırım and Şimşek, 2011).

\section{Study Group}

The study group of the research consists of 110 undergraduate students from Dokuz Eylül University, who are volunteers for the research, studying in Faculty of Education, Department of Science Teaching, Department of Primary Education, Department of Turkish Education and Faculty of Theology, in the 20192020 academic years. $15.45 \%$ of the study group is in the Department of Primary Education $(n=17), 11.81 \%$ is in the Department of Science Teaching $(\mathrm{n}=13), 28.18 \%$ is in the Department of Turkish Education $(\mathrm{n}=31)$, and $44,54 \%$ of them are students of the Faculty of Theology $(n=49) .19 \%$ of students are in 1 st grade $(n=21), 29 \%$ are in $2^{\text {nd }}$ grade $(n=32), 31.8 \%$ are in $3^{\text {rd }}$ grade $(n=35), 20 \%$ are in $4^{\text {th }}$ grade $(n=22)$. 


\section{Data collection tool}

In this study, in which university students' metaphoric perceptions of musician and artist concepts were determined, semi-structured interview technique was used as data collection tool. The metaphors formed by the students were collected with a semi-structured interview form consisting of 2 questions. In the form, each student was asked to complete the following sentences, depending on her/his perception: "An artist is like..., because..." and "A musician is like..., because..." In this question form, the "like" word is often used to more clearly evoke the link between "the subject of metaphor" and "the source of metaphor" (Ekici, Akdeniz, 2018).

\section{Data Analysis}

The following steps were taken in the analysis of the data obtained:

\section{$1^{\text {st }}$ stage}

First of all, the study group was informed about study and metaphor for 20 minutes. Afterwards, they were given 20 minutes to complete the form.

\section{$2^{\text {nd }}$ Stage}

The collected forms were numbered from 1 to 110, respectively. In accordance with the consensus of 1 professor, 1 associate professor and 1 lecturer from the field of music education, and an associate professor from the Department of Turkish Education, metaphors which were not related to the subject were discarded. As a result of the evaluation, 85 metaphors in musician category and 90 metaphors in artist category were processed and listed.

\section{$3^{\text {rd }}$ Stage}

At this stage, the data were analyzed in Nvivo qualitative data analysis program. Similar metaphors identified in Nvivo are classified and categorized based on expert opinions. Identified metaphors and metaphor categories containing similar expressions are listed as percentage and frequency.

\section{Validity-Reliability}

For the reliability of the research, the data obtained were analyzed by the researcher and 3 experts, and metaphors and categories were determined. In this study, the reliability formula of Miles and Huberman (1994) was applied to determine the reliability based on consensus and disagreement. This formula is as follows: Reliability $=$ Consensus $/$ Consensus + Disagreement. The reliability value of the study was found to be $91 \%$. According to this value, the study was found to be reliable. According to Miles and Huberman, $90 \%$ and above values obtained from this formula are sufficient for reliability. Categories with "consensus" were accepted as they are, and reorganization was made for those with "disagreement". There was no need for a new separate categorization for some metaphors, and an evaluation was made on existing categories.

\section{Findings}

In this section, first of all, metaphors produced by university students for the concept of artists and musicians are classified according to the most frequently repeated and least repeated (Table 1 and 3 ). Then the metaphors used were categorized according to the meaning they express (Table 2 and 4). 
Table 1. Metaphors produced by university students for the concept of artist

\begin{tabular}{|c|c|c|c|c|c|c|c|}
\hline Metaphor Rank & Metaphor name & $f$ & $\%$ & Metaphor Rank & Metaphor name & $f$ & $\%$ \\
\hline 1 & Mirror & 5 & 5,5 & 32 & Lifeblood & 1 & 1,1 \\
\hline 2 & Sun & 5 & 5,5 & 33 & Lover & 1 & 1,1 \\
\hline 3 & Sky & 4 & 4,4 & 34 & Water & 1 & 1,1 \\
\hline 4 & Teacher & 4 & 4,4 & 35 & Atom & 1 & 1,1 \\
\hline 5 & Sea & 4 & 4,4 & 36 & Oxygen & 1 & 1,1 \\
\hline 6 & Light & 3 & 3,3 & 37 & Air & 1 & 1,1 \\
\hline 7 & Door & 2 & 2,2 & 38 & Harmony & 1 & 1,1 \\
\hline 8 & Architect & 2 & 2,2 & 39 & Writer & 1 & 1,1 \\
\hline 9 & Diamond & 2 & 2,2 & 40 & Candle & 1 & 1,1 \\
\hline 10 & Nature & 2 & 2,2 & 41 & Forest & 1 & 1,1 \\
\hline 11 & Ocean & 2 & 2,2 & 42 & Time & 1 & 1,1 \\
\hline 12 & Love & 2 & 2,2 & 43 & Shelter & 1 & 1,1 \\
\hline 13 & Professor & 2 & 2,2 & 44 & Root & 1 & 1,1 \\
\hline 14 & Heart & 2 & 2,2 & 45 & Family & 1 & 1,1 \\
\hline 15 & Painting & 2 & 2,2 & 46 & Bread & 1 & 1,1 \\
\hline 16 & Vein & 1 & 1,1 & 47 & Doctor & 1 & 1,1 \\
\hline 17 & Explorer & 1 & 1,1 & 48 & Screenwriter & 1 & 1,1 \\
\hline 18 & Guide & 1 & 1,1 & 49 & Athlete & 1 & 1,1 \\
\hline 19 & Leader & 1 & 1,1 & 50 & Life & 1 & 1,1 \\
\hline 20 & Master & 1 & 1,1 & 51 & Surgeon & 1 & 1,1 \\
\hline 21 & Pioneer & 1 & 1,1 & 52 & Universe & 1 & 1,1 \\
\hline 22 & Lamp & 1 & 1,1 & 53 & Carpenter & 1 & 1,1 \\
\hline 23 & Horizon & 1 & 1,1 & 54 & Flower & 1 & 1,1 \\
\hline 24 & Salt & 1 & 1,1 & 55 & Bird & 1 & 1,1 \\
\hline 25 & Rope & 1 & 1,1 & 56 & Cook & 1 & 1,1 \\
\hline 26 & Traveler & 1 & 1,1 & 57 & Cloud & 1 & 1,1 \\
\hline 27 & Hand & 1 & 1,1 & 58 & DNA & 1 & 1,1 \\
\hline 28 & Pillow & 1 & 1,1 & 59 & Road & 1 & 1,1 \\
\hline 29 & Farmer & 1 & 1,1 & 60 & Rainbow & 1 & 1,1 \\
\hline 30 & Key & 1 & 1,1 & 61 & Acrobat & 1 & 1,1 \\
\hline \multirow[t]{2}{*}{31} & Television & 1 & 1,1 & 62 & Magician & 1 & 1,1 \\
\hline & & & & & Total 62 & 90 & 100 \\
\hline
\end{tabular}

When Table 1 is examined; it is seen that university students produce 62 kinds of metaphors out of a total of 90 views on the concept of "artist". The metaphors that the university students most produce for the concept of artists are mirror (5), sun (5), sky (4), teacher (4), sea (4), light (3), television (2), door (2), architect (2), nature (2), diamond (2), ocean (2), love (2), professor (2), painting (2), and heart (2). A total of 43 metaphors were repeated between 2 and 5 times, while 47 metaphors were used once. As it can be seen from Table 1, the most used metaphors by university students for the concept of artist are mirror, sun, sky, teacher, sea, and light. 
Table 2. Distribution of metaphors developed by university students towards the concept of "artist" by category

\begin{tabular}{|c|c|c|c|}
\hline Categories & Metaphor names & $\begin{array}{l}\text { Metaphor } \\
\text { Number }\end{array}$ & $\begin{array}{l}\text { Metaphor frequency } \\
\text { (student number) }\end{array}$ \\
\hline 1.Artist as "enlightener" & $\begin{array}{l}\text { Mirror (5), sun (5), light (3), teacher (4), } \\
\text { professor (2), lamp (1), guide (1), leader } \\
(1) \text {, pioneer (1), root (1), explorer (1), } \\
\text { television (1), life (1), road (1) }\end{array}$ & 14 & 28 \\
\hline 2. Artist as "freedom" & $\begin{array}{l}\text { Sky }(2) \text {, sea }(2) \text {, ocean }(2) \text {, bird (1), cloud } \\
(1) \text {, water (1), time (1), horizon (1), } \\
\text { bread (1), salt (1) }\end{array}$ & 11 & 14 \\
\hline 3. Artist as "creator" & $\begin{array}{l}\text { hand }(1) \text {, farmer }(1) \text {, master (1), } \\
\text { screenwriter (1), carpenter (1), cook (1), } \\
\text { writer (1), architect (1), magician (1), } \\
\text { acrobat (1), surgeon (1) }\end{array}$ & 11 & 11 \\
\hline 4. Artist as "relaxing" & $\begin{array}{l}\text { Love }(2) \text {, sea }(2) \text {, forest }(1) \text {, nature }(1) \text {, } \\
\text { pillow (1), shelter }(1) \text {, sky (1), traveler } \\
(1)\end{array}$ & 8 & 10 \\
\hline 5. Artist as "importance" & $\begin{array}{l}\text { Heart (2), door (2) lifeblood (1), oxygen } \\
(1), \text { key }(1) \text {, vein }(1), \text { atom }(1) \text {, air (1) }\end{array}$ & 8 & 10 \\
\hline 6. Artist as "authenticity" & $\begin{array}{l}\text { Painting (2), diamond (2), candle (1), } \\
\text { DNA (1) }\end{array}$ & 4 & 6 \\
\hline 7. Artist as "beauty" & $\begin{array}{l}\text { Sky (2), nature (1), flower (1), rainbow } \\
\text { (1) }\end{array}$ & 4 & 4 \\
\hline 8. Artist as "profession" & Lover (1), athlete (1), doctor (1) & 3 & 3 \\
\hline 9. Artist as "unifying" & Rope (1), family (1), harmony (1), & 3 & 3 \\
\hline & Total & 66 & 90 \\
\hline
\end{tabular}

When the metaphors created by university students for the concept of artist were classified, 9 categories were identified. As seen in Table 2, the most metaphor-produced categories are; artist (14) as "enlightener", artist (11) as an expression of "freedom", artist (11) as "creator", and artist (8) as relaxing, and artist (8) as an expression of "importance". Other categories are as follows; artist (4) as authenticity, artist (4) as an expression of beauty, artist (3) as profession, and artist (3) as unifying. Metaphors having the same name have been repeated in different categories according to their meaning.

Sample descriptions of some of the metaphors created for the above-mentioned categories are as follows:

\section{Category 1: Artist as "Enlightener"}

In this category, metaphors about the social function and experienced side of the concept of artist are included. It was stated that the artist guided the society and life, and shed light on them. Metaphors used are mirror, sun, teacher, light, professor, lamp, guide, leader, pioneer, root, explorer, television, life, and road.

An artist is like a mirror. Because s/he reflects society (K8).

An artist is like a root. Because s/he carries the things from the past to the future (K19).

An artist is like an explorer. Because s/he turns what s/he discovers into art and opens the horizons of humanity (K38).

An artist is like a guide for the society. Because s/he guides people with her/his art (K75).

An artist is like the life itself. Because s/he draws lessons from her/his experiences in life (K45). 
An artist is like a road. Because the things s/he sees on all the roads s/he goes contribute to her/his art (K73).

\section{Category 2: Artist as "Freedom"}

This category includes metaphors where the concept of artist is associated with expressions of freedom and infinity. Metaphors created in this category are sky, sea, ocean, bird, cloud, water, time, horizon, universe, bread, and salt.

An artist is like the sky. Because s/he surrounds the human's inner world and the whole world (K7).

An artist is like a sea. Because s/he is endless (K50).

An artist is like an ocean. Because s/he has endless imagination (K67).

An artist is like a bird. Because s/he flies freely like a bird and takes her/his art to a unique dimension and flies in this dimension (K62).

An artist is like a cloud. Because s/he must be free like a cloud to produce (K64).

An artist is like the universe. Because s/he has no end, s/he is endless (K55).

\section{Category 3: Artist as "Creator"}

In this category, metaphors that emphasize the creation, production, design, and talent aspects of the artist concept are included. The artist's creation of artwork is expressed by metaphors such as architect, hand, farmer, master, screenwriter, carpenter, cook, writer, magician, acrobat and surgeon.

"An artist is like an architect. Because s/he presents something new." (K14)

"An artist is like a farmer. Because s/he always grows new products." (K35)

"An artist is like a master. Because s/he adds aesthetics to her/his work in whatever field." (K17)

"An artist is like a carpenter. Because like a carpenter shapes a tree, an artist shapes the art s/he is engaged in." (K11)

"An artist is like a surgeon. Because like a surgeon saves lives with her/his knife, an artist connects people to life with her/his works (K41).

"An artist is like a tightrope walker. Because being an artist is as difficult as walking on a rope (K88).

\section{Category 4: Artist as "Relaxing"}

In this category, metaphors, in which relaxing and emotional aspects of artist concept are emphasized, are included. The fact that the artist has a relaxing effect with the works of art is expressed by metaphors such as forest, nature, sea, pillow, shelter, sky, traveler and love.

An artist is like a traveler. Because s/he travels among all emotions (K28).

An artist is like love. Because s/he always experiences intense emotions to produce (K4 0)

An artist is like a forest. Because s/he gives peace to souls of persons (K3).

An artist is like the sea. Because s/he is peace (K25)

An artist is like a pillow because we lean on her/him to get rid of all the fatigue of life (K33).

\section{Category 5: Artist as "Importance"}

In this category, metaphors regarding the importance of the artist concept are given. The importance of the artist for the world and the humanity is expressed with metaphors like lifeblood, air, heart, vein, and atom. 
An artist is like lifeblood of a society. Because without the artist, a society cannot live. (K74)

An artist is like a heart. Because it is a sign that one lives. (K100)

An artist is like an atom. Because s/he influences everything. (K17)

An artist is like air. Because s/he makes people feel that they are living. (K61)

\section{Category 6: Artist as "Authenticity"}

In this category, metaphors in which the concept of artist is associated with expressions of authenticity are included. Metaphors created in this category are painting, DNA, diamond and candle.

An artist is like a painting. Because as we understand her/him, we discover new things. (K69)

An artist is like DNA. Because s/he has her/his own style. (K53)

An artist is like a diamond. Because s/he is always precious. (K72)

An artist is like a candle. Because s/he won't lose a thing from her/his fire by lighting other candles. $(\mathrm{K} 84)$

\section{Category 7: Artist as "Beauty"}

In this category, metaphors, in which the concept of artist is associated with expressions of beauty, are included. The metaphors created in this category are nature, flower, sky and rainbow.

An artist is like nature. Because s/he reflects the beauties of nature. (K20)

An artist is like a flower. Because s/he adds beauty to our lives. (K58)

An artist is like the sky. Because s/he makes people feel refreshed. (K92)

An artist is like a rainbow. Because s/he transfers many different spirits and colors. (K80)

\section{Category: 8. Artist as "Profession"}

In this category, metaphors, that emphasize the professional aspect of the artist concept, are included. The artist as a profession is expressed with metaphors like lover, athlete and doctor.

An artist is like an athlete. Because in order not to lose her/his skills, s/he must always practice (K44).

An artist is like a doctor. Because s/he cures with art (K93).

\section{Category 9. Artist as "Unifying"}

This category includes metaphors for the unifying function of the artist concept. Metaphors used for the unifying power of the artist are rope, family, and harmony.

An artist is like a rope. Because s/he connects us. (K24)

An artist is like family. Because s/he is always there for you. (K94)

An artist is harmony. Because s/he ensures the harmony of differences. (K72)

The data obtained from the study were evaluated and a model of the cognitive structures of university students related to the artist concept was formed (Model 1). 


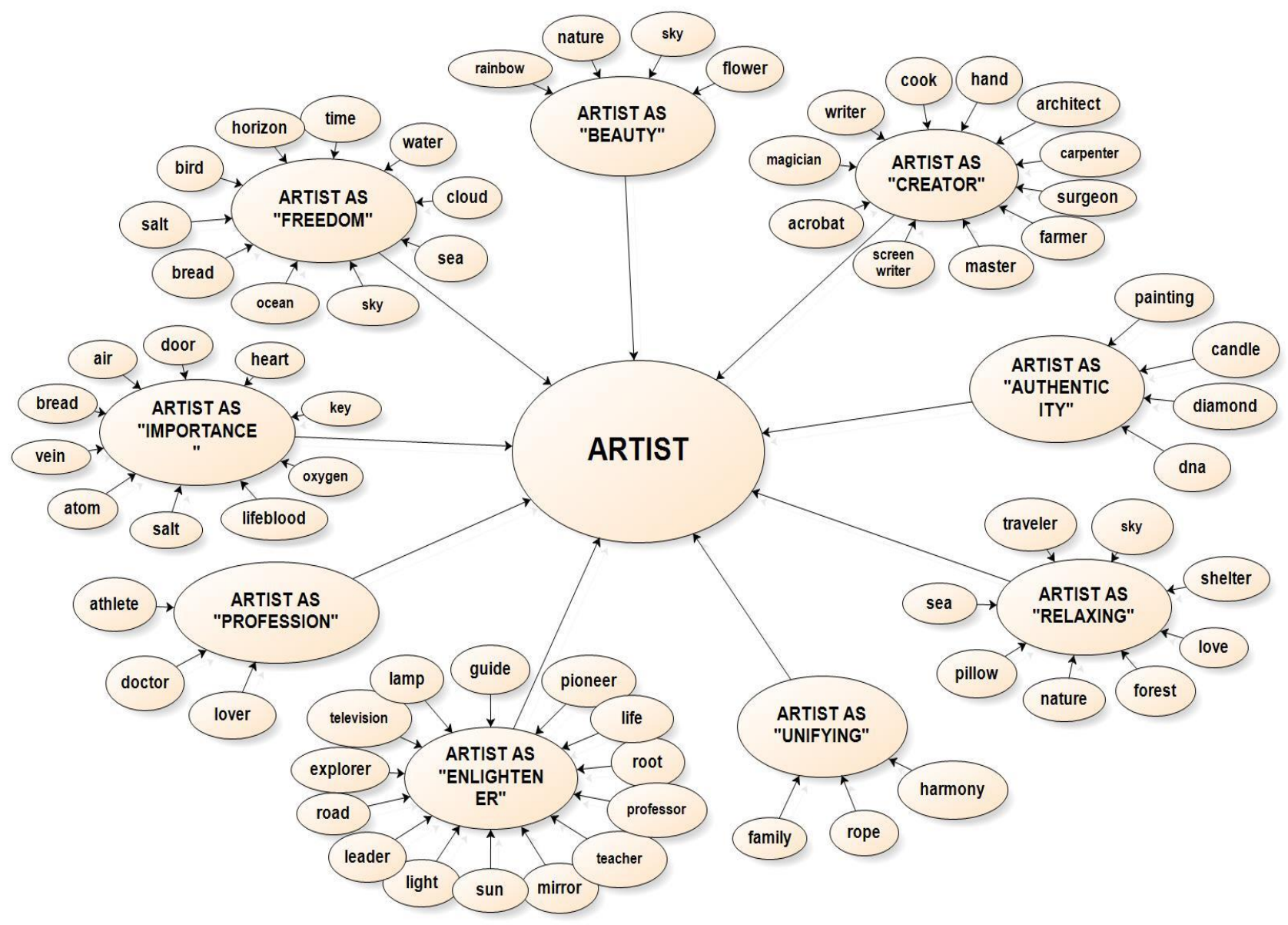

Model 1. The model showing the metaphoric perceptions of university students about the concept of artist.

Table 3. Metaphors developed by university students for the concept of "musicianship"

\begin{tabular}{|c|c|c|c|c|c|c|c|}
\hline $\begin{array}{l}\text { Metaphor } \\
\text { rank }\end{array}$ & $\begin{array}{l}\text { Metaphor } \\
\text { name }\end{array}$ & $f$ & $\%$ & $\begin{array}{l}\text { Metaphor } \\
\text { rank }\end{array}$ & $\begin{array}{l}\text { Metaphor } \\
\text { name }\end{array}$ & $f$ & $\%$ \\
\hline 1 & Spirit & 4 & 4,68 & 34 & Leader & 1 & 1,17 \\
\hline 2 & Book & 4 & 4,68 & 35 & Host & 1 & 1,17 \\
\hline 3 & Sea & 3 & 3,51 & 36 & Seed & 1 & 1,17 \\
\hline 4 & School & 3 & 3,51 & 37 & Happiness & 1 & 1,17 \\
\hline 5 & Tree & 3 & 3,51 & 38 & Water & 1 & 1,17 \\
\hline 6 & Light & 2 & 2,34 & 39 & Food & 1 & 1,17 \\
\hline 7 & Cook & 2 & 2,34 & 40 & Chocolate & 1 & 1,17 \\
\hline 8 & $\begin{array}{l}\text { Psychologi } \\
\text { st }\end{array}$ & 2 & 2,34 & 41 & Love & 1 & 1,17 \\
\hline 9 & $\begin{array}{l}\text { School } \\
\text { Principal }\end{array}$ & 2 & 2,34 & 42 & Dessert & 1 & 1,17 \\
\hline 10 & Sun & 2 & 2,34 & 43 & Forest & 1 & 1,17 \\
\hline 11 & Flower & 2 & 2,34 & 44 & Offspring & 1 & 1,17 \\
\hline 12 & Life & 2 & 2,34 & 45 & Indispensle & 1 & 1,17 \\
\hline 13 & Computer & 2 & 2,34 & 46 & $\begin{array}{l}\text { Rhythm of } \\
\text { the human }\end{array}$ & 1 & 1,17 \\
\hline 14 & $\begin{array}{l}\text { Unity of } \\
\text { existence }\end{array}$ & 1 & 1,17 & 47 & Bird & 1 & 1,17 \\
\hline 15 & Cloud & 1 & 1,17 & 48 & Hope & 1 & 1,17 \\
\hline 16 & Cook & 1 & 1,17 & 49 & Child & 1 & 1,17 \\
\hline
\end{tabular}




$\begin{array}{llllllll}17 & \text { Voice in me } & 1 & 1,17 & 50 & \text { Door } & 1 & 1,17 \\ 18 & \text { Picture } & 1 & 1,17 & 51 & \text { Painter } & 1 & 1,17 \\ 19 & \text { Poem } & 1 & 1,17 & 52 & \text { Artist } & 1 & 1,17 \\ 20 & \text { Painting } & 1 & 1,17 & 53 & \text { Star } & 1 & 1,17 \\ 21 & \text { Music note } & 1 & 1,17 & 54 & \text { Architect } & 1 & 1,17 \\ 22 & \text { Freedom } & 1 & 1,17 & 55 & \text { Carpenter } & 1 & 1,17 \\ 23 & \text { Car } & 1 & 1,17 & 56 & \text { Sculpture } & 1 & 1,17 \\ 24 & \text { Coffee } & 1 & 1,17 & 57 & \text { Mixture } & 1 & 1,17 \\ 25 & \text { Teacher } & 1 & 1,17 & 58 & \text { Magicwad } & 1 & 1,17 \\ 26 & \text { Ocean } & 1 & 1,17 & 59 & \text { Doctor } & 1 & 1,17 \\ 27 & \text { Mathemati } & 1 & 1,17 & 60 & \text { Medicine } & 1 & 1,17 \\ & \text { cian } & & & & & 1,17 \\ 28 & \text { Wind } & 1 & 1,17 & 61 & \text { Gem } & 1 & 1,17 \\ 29 & \text { Textbook } & 1 & 1,17 & 62 & \text { Signature } & 1 & 1,17 \\ 30 & \text { Chemistry } & 1 & 1,17 & 63 & \text { Antique } & 1 & 1,17 \\ 31 & \text { Torch } & 1 & 1,17 & 64 & \text { Diamond } & 1 & 1,17 \\ 32 & \text { Orchestra } & 1 & 1,17 & 65 & \text { Mother } & 1 & \\ 33 & \text { Puzzle } & 1 & 1,17 & & & & \mathbf{1 0 0} \\ & & & & & & \\ \end{array}$

When Table 3 is examined, it is seen that university students produce 65 kinds of metaphors from 85 views regarding the concept of "musician". The most produced metaphors of university students for the concept of musician are spirit (4), book (4), school (3), sea (3), tree (3), light (2), cook (2), psychologist (2), school principal (2), sun (2), flower (2), life (2), and computer (2). A total of 33 metaphors are repeated between 2 and 4 times, while 52 metaphors are used once. As can be seen from Table 3, it is seen that the metaphors most used by university students for the concept of musician are spirit, book, school, sea, and tree.

Table 4. Distribution of metaphors developed by university students for the concept of "musicianship" by categories

\begin{tabular}{|c|c|c|c|}
\hline Categories & Metaphor names & $\begin{array}{l}\text { Metaphor } \\
\text { Number }\end{array}$ & $\begin{array}{l}\text { Metaphor } \\
\text { frequency (student } \\
\text { number) }\end{array}$ \\
\hline $\begin{array}{l}\text { 1. Musician as an expression } \\
\text { of "abstractness" }\end{array}$ & $\begin{array}{l}\text { Sea }(2) \text {, spirit }(2) \text {, ocean }(1) \text {, book }(1) \text {, unity } \\
\text { of existence }(1) \text {, wind }(1) \text {, cloud }(1) \text {, tree }(1) \text {, } \\
\text { flower }(1) \text {, cook }(1) \text {, voice in me }(1) \text {, picture } \\
(1) \text {, poem }(1) \text {, painting }(1) \text {, music note }(1) \text {, } \\
\text { freedom }(1) \text {, car }(1) \text {, coffee }(1)\end{array}$ & 18 & 20 \\
\hline
\end{tabular}

$\begin{array}{lll}\text { 2. Musician as "educator- } & \text { School (3), school principal (2), light (2), } & 16 \\ \text { instructor" } & \text { sun (2), teacher (1), tree (1), life (1), } \\ & \text { mathematician (1), book (1), computer (1), } \\ & \text { textbook (1), chemistry (1), torch (1), leader } \\ & (1), \text { host (1), seed (1) } \\ & \text { Book (1), happiness(1), water (1), food (1), } 15 \\ \text { 3. Musician as "relaxing- } & \text { chocolate (1), love (1), dessert (1), sea (1), } \\ \text { pleasing" } & \text { forest (1), offspring (1), indispensable (1), } \\ & \text { rhythm of the human (1), bird (1), hope (1), } \\ & \text { child (1) }\end{array}$




\begin{tabular}{|c|c|c|c|}
\hline 4. Musician as "creativity" & $\begin{array}{l}\text { Cook (2), door (1), painter (1), artist (1), } \\
\text { farmer (1), star (1), architect (1), sculptor } \\
(1) \text {, carpenter (1), mixture (1), book (1), tree } \\
(1) \text {, magic wand (1) }\end{array}$ & 13 & 14 \\
\hline 5. Musician as "healer" & $\begin{array}{l}\text { Psychologist (2), spirit (2), doctor (1), life } \\
(1) \text {, medication (1) }\end{array}$ & 5 & 7 \\
\hline 6. Musician as "value" & $\begin{array}{l}\text { Gem (1), signature (1), antique (1), } \\
\text { diamond (1) }\end{array}$ & 4 & 4 \\
\hline 7. Musician as "unifying" & $\begin{array}{l}\text { Orchestra (1), computer (1), mother (1), } \\
\text { puzzle (1) }\end{array}$ & 4 & 4 \\
\hline & Total & 75 & 85 \\
\hline
\end{tabular}

Sample descriptions of some of the metaphors created for the above-mentioned categories are as follows:

\section{Category 1: Musician as "Abstractness"}

In this category, metaphors for the abstractness function as well as the expression of emotions of the musician concept are included. Metaphors used are sea, spirit, ocean, book, unity of existence, wind, cloud, tree, flower, cook, voice in me, picture, poetry, painting, musical note, car, coffee and freedom.

A musician is a person who speaks to the spirit. Because s/he refresh the spirit(K11).

A musician is like freedom. Because s/he performs the music as s/he likes (K58).

A musician seems to be at the level of unity of existence (fenafillah). Because $\mathrm{s} / \mathrm{he}$ has now turned into music (K7).

A musician is like a sea. Because s/he is relaxing (K66).

A musician is like a flower. Because s/he covers all emotions like flowers (K61).

A musician is like wind. Because there are spirits s/he hurls (K23).

A musician is like the voice in me. Because s/he reflects my thoughts very well (K77).

A musician is like a painting. Because s/he tells many things in her/his works (K51).

A musician is like a music note. Because s/he expresses things that people cannot (K87).

A musician is like a car. Because s/he takes us to different memories (K22).

A musician is like coffee. Because s/he may be remembered for forty years (K52).

\section{Category 2: Musician as an "Educator-Trainer"}

In this category, metaphors about the importance musician of the concept in educational/ instructive, enlightening and informative aspects are included. Metaphors used are school, school principal, light, sun, teacher, tree, life, mathematician, book, computer, textbook, chemistry, torch, leader, host and seed.

A musician is like a school. Because s/he develops people. (K9)

A musician is like a tree. Because s/he flourishes with her/his education and skills. (K50)

A musician is like life. Because struggle for education does not end. (K59)

A musician is like a book. Because s/he both educates and teaches. (K5)

A musician is like all lessons book. Because s/he contains everything. (K37) 
A musician is like the sun. Because s/he enlightens people. (K86)

A musician is like a computer. Because s/he knows everything about music. (K27)

A musician is like a school. Because s/he contains the most valuable information. (K71)

A musician is like a torch. Because s/he reflects the light of society. (K89)

A musician is like light. Because s/he directs and guides the art. (K48)

A musician is like the sun. Because s/he enlightens her/his surroundings. (K72)

A musician is like a leader. Because s/he leaves permanent marks on all people. (K15)

\section{Category 3: Musician as "Relaxing-Pleasing"}

In this category, metaphors for peace/happiness and life source of musician concept are included. Metaphors used are book, happiness, water, food, chocolate, love, dessert, sea, forest, offspring, indispensable, rhythm of the human, bird, hope, and child.

A musician is like chocolate. Because s/he sweetens life. K88)

A musician is like happiness. Because s/he makes one happy. (K76)

A musician is like a forest. Because you go there to find peace. (K20)

A musician is like a sea. Because s/he makes people relax and give them peace. (K38)

A musician seems to be indispensable. Because s/he is the source of life for humans. (K19)

A musician is like a rhythm of human. Because if this rhythm does not happen, s/he is missing (K65).

The musician is like a son. Because it can be a source of joy (K1).

A musician is like a child. Because it is fun, active, full of life (K53).

A musician seems to be indispensable. Because it is the source of life for man (K19).

A musician is like a rhythm of man. Because if this rhythm does not happen, he is missing (K65).

A musician is like an offspring. Because s/he can be a source of joy (K1).

A musician is like a child. Because s/he is fun, active, and full of life (K53).

\section{Category 4: Musician as "Creativity"}

In this category, metaphors, in which creation, production, design and talent aspects of musician concept are emphasized, are included. The musician is expressed with metaphors like cook, door, painter, artist, farmer, star, architect, sculptor, carpenter, mixture, book, tree, magic wand.

A musician is like a cook. Because s/he makes a nice meal with elements such as rhythm and music." $(\mathrm{K} 8)$

A musician is like a farmer. Because $\mathrm{s} / \mathrm{he}$ makes music by processing sounds. (K8)

A musician is like a painter. Because both are creative artists." (K82)

A musician is like sculptor. Because sometimes s/he even shapes our thoughts." (K33)

A musician is like a carpenter. Because s/he creates a new dimension with authentic notes. K (K47)

A musician is like a tree. Because s/he grows with education and ability. (K81)

A musician is like a mixture. Because s/he plays most musical instruments. (K49) 
A musician is like a magic wand. Because s/he has little touches in songs. (K74)

\section{Category 5: Musician as "Healer"}

In this category, metaphors emphasizing the healing power of the musician concept are included. Metaphors used are psychologist, spirit, doctor, life, and medication.

A musician is like a psychologist. Because $s /$ he is like the individuals who consciously nurture one's emotions. (K73)

A musician is like a doctor. Because s/he touches the depressions in our souls and repairs them." (K3)

A musician is like the spirit. Because s/he nourishes the spirit." (K18)

A musician is like life. Because when you are desperate, s/he gives you hope." (K14)

\section{Category 6: Musician as "Value"}

In this category, metaphors emphasizing the musician concept's contribution as value are included. In this category, the musician is expressed with metaphors such as gem, signature, antique, and diamond.

A musician is like a diamond. Because $\mathrm{s} / \mathrm{he}$ is precious and rare. (K4)

A musician is like a gem. Because s/he shines. (K2)

A musician is like an antique object. Because as time goes by, her/his value increases. (K26)

\section{Category 7: Musician as "Unifying"}

This category includes metaphors for the unifying power of the musician concept. Metaphors used are orchestra, computer, mother and puzzle.

A musician is like a mother. Because s/he holds people together. (K63)

A musician is like a puzzle. Because s/he tacks all the pieces of music and completes the music. (K21)

A musician is like a computer. Because it is difficult for her/him to work without a part. (K36)

The data obtained from the study were evaluated and a model of the cognitive structures of university students related to the concept of musician was formed (Model 2). 


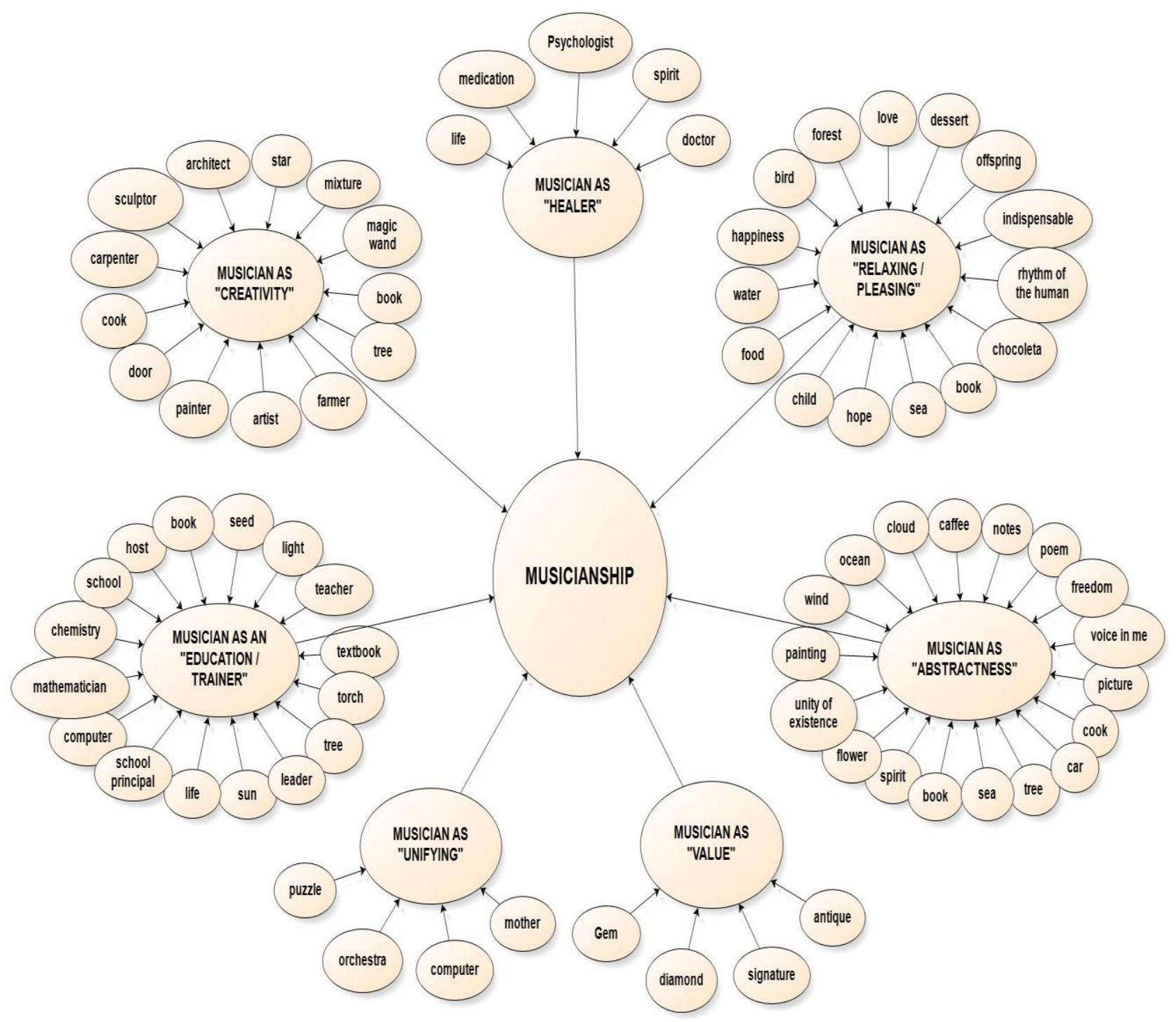

Model 2. The model showing the metaphoric perceptions of university students about the concept of musician.

\section{Conclusion and Discussion}

According to the results of the research, the metaphors used by university students regarding the concept of "artist" are collected under the categories of artist as enlightener, artist as freedom, artist as creator, artists as relaxing, artist as importance, artist as authenticity, artist as beauty, artist as profession, and artist as unifying.

When the studies in the literature are examined, it is seen that metaphor studies related to the concept of "artist" is in limited number; however, some studies related to "art" and "art education" have been encountered. Regarding the "artist", Yalcin Wells (2015), in her study with undergraduate students from painting department, collected the metaphors used for the "artist" under the categories of enlightening and guiding, expression of creativity and freedom, authentic, and gaining a place/persistent. These results showed that the research coincided with the categories of artists as enlightening, freedom, authenticity and importance. Regarding the art and art education; in the study of Akdeniz and Çarıkçı (2017), the opinions of the students of the conservatory about art education were taken and it was seen that the "creativity" aspect came to the fore. In the study of Hiçyılmaz and Adanır (2019), carried with prospective teachers, the concept of art was defined as freedom, creativity and a part of life, and the results obtained from this study overlap 
with the categories of "artist as creator", "artist as freedom", and "artist as importance", in the dimension of artartist relationship. In the study of Kalyoncu (2013) with prospective primary school teachers, categories like "a part of life" and "creativity" are similar to the categories of "artist as importance" and "artist as creator". It is observed that creativity, enlightening and guiding, expressing freedom, being a part of life, and characteristics related to authenticity are in the forefront in studies on art, art education and artists, and these categories are common in students both having vocational art education and not having this education. Accordingly, it is seen that art and artist are perceived as elements that shed light on society with an innovative and creative approach. Artists are often described as the forerunners of social changes, and thus form an integral integrity with developments and changes in society (as cited in Novak-Leonard and Skaggs; 2017). In the research, it is seen that peace, beauty, profession and unifying features related to the concept of artist differ with the work of Yalcin Wells (2015) with the students of the art department (painting-work education) and it is thought that this difference is due to the fact that these two study groups consist of those who are and are not students of art department. These different categories were similar with the ones in the study of Hicyilmaz and Adanir (2017) and Kalyoncu (2013) with university students who were not in the art education department. In these studies, it was seen that the perceptions about the concepts of art and art education were mostly in emotional dimension. In studies conducted with students who are not in the department of art, the concept of art was defined as a way of emotional expression, source of pleasure, expression of love and emotions. In this sense, it is understood from the categories of artists as relaxing and beauty in the research that the perceptions about art and artist are defined in an emotional dimension.

According to the results of the research, the metaphors used by the university students regarding the concept of "musician" were gathered under the categories of musician as expression of abstractness, musician as educator-trainer, musician as relaxing and pleasing, musician as creativity, musician as healer, musician as value, and musician as unifying. However, there has been no study related to the concept of musician in the literature but there are various metaphor studies about the concept of music and music education. In the study, relaxing and pleasing, unifying properties obtained from the participants for the musician overlap with Çimen and Ozevin's (2019) study with the categories of relaxing, resting-giving peace, needed, integrative-uniting. Similarly, it is seen that "relaxing-pleasing" and "unifying" features of the research for the musician overlap with "giving peace" of the music lesson in the work of Açıkgöz (2017); and with "integrative" feature in Cevik K1lıç's (2017) study. In the study of Umuzdaş and Umuzdaş (2013) students of primary school teaching states that music lesson is a pleasing one and gives the ability to cooperate, and this situation is similar to the research's relaxing-pleasing aspect and a unifying factor created for the musician. Although there is no direct study on the concept of musician, it is seen that some of the perceptions about music are also used for the musician. The reason for this is that the affective dimension that music creates on the individual may directly affect the perception about the musician. In addition to these, although no negative perception about the concept of musician was found in the research, some negative perceptions about music and music lessons were found in some of the abovementioned studies (Cimen and Ozevin, 2019; Umuzdas \& Umuzdas, 2013). When the results, related to music and musician, were examined, it was seen that the perceptions of the participants about these concepts were mostly emotional and related to their connotations. The fact that the definitions made about musicianship have mostly relaxing-pleasing, educational but also unifying features makes us think that the definitions are in emotional dimension. It can be assumed that these expressions also include the roles determined for the musician and the participant's thoughts on what is expected from her/him and the music s/he makes. At this point, again, it may be possible to talk about individual perceptions and roles determined in the light of cultural effects.

When the results obtained from the research are analyzed, it is seen that the creativity, relaxing and unifying features are used by the university students for both of "artist" and "musician" concepts. Accordingly, the participants use metaphors that define these categories while explaining their perceptions 
about both concepts. Among them, metaphors that make up the "creator" category are frequently used when explaining the concept of "artist" and "musician". Although the concept of creativity is one of the most prominent features of the artist, it can be assumed that there is a certain amount of creativity in the interpretation of a work of the musician. In addition to this, creativity dimension in the concept of artist and musician can be interpreted differently by people who are and are not musicians. When the current studies are analyzed, it is seen that both the students who have received art education at a professional level and those who have not, have made definitions regarding the "creativity" feature. At what point the product put forth has artistic value and at what point the musician is considered as an artist can depend on personal perceptions, experiences and cultural influences. Barton (2018) emphasized the effect of culture on music and sometimes the effect of music on cultural expression and stated that culture and life experience cannot be separated in the concept of music. In this context, it seems inevitable to have a variety of meanings regarding the concepts of artists and musicians in proportion to personal and professional experiences and cultural influences. While it is seen that the word artist is used for musicians from time to time, it is seen that according to the glossary of terms, the meaning of the artist includes "musician" as "someone who has a special talent in performing in an art branch in which the creative action depends on aesthetic evaluation, imagination and authenticity, someone who creates a work of art, plays in created works of art, interprets and applies them".

While the perceptions of the people who receive art education in the professional dimension about the concept of "artist" and "musician" show their own characteristics, university students who can define artist and musician as outsiders, who are at the top stage of their formal education, who can produce definitions regarding these concepts and study in fields other than art are counted as individuals who represent a wider audience with their perceptions about "artist" and "musician", and their awareness and perceptions about these concepts, which they frequently encounter in daily life, are aimed to be understood.

According to this;

Although discussions about who is an artist often appear in daily life, very few studies have been encountered about the musician and artist in the literature and it is seen that it is necessary to conduct studies in which the concepts are evaluated together with the concepts of music and art. In addition to these, with individuals who are and are not musicians or who are and are not students in the arts education department, with working groups of different walk of life and of different age groups, understanding and evaluating their perceptions about music, musician, art and artist concepts and the evaluation of the psychological, sociological, cultural, and social dimensions of the effects forming these perceptions can be done comparatively for both groups. The causes of the positive/negative perceptions obtained should be addressed, and within this framework, improvements to music education and art education should be reevaluated and the improvements that can be made through the understanding of education should be emphasized.

In the process of university education, it is expected that not only professional skills but also intellectual gains are formed. When the results of the study were examined, it was seen that common categories such as creativity, relaxing and unifying were formed for the concepts of artist and musician. This situation raises questions such as at what stage to produce a work or should it involve creativity, do the artist and musician have a mission such as producing relaxing works. Does producing something new always mean creating, or is every product a work of art? Today, the word art is used for many areas outside music, painting, theater, etc. It. For example, culinary arts, clothing arts. In this case, what are the place of the artist and the place of the musician in all these definitions of art? In this context, it is important to understand the perceptions formed for these concepts. Also, the participation of university students and also teacher candidates in the study group of the research should be encouraged to participate in artistic activities and a suitable environment should be prepared for this, art should be further included in the curriculum, and the opportunity should be provided so that their perceptions about the subject can be shaped by their own experiences. 


\section{REFERENCE}

Acikgoz, N. (2017). Ortaokul Öğrencilerinin Müzik Dersine İlişkin Metafor Örneklerinin İncelenmesi. (Yayınlanmamış Yüksek Lisans Tezi). (Examining Secondary School Students' Metaphor Examples Regarding Music Lesson). (Unpublished Master's Thesis). Inonu University Institute of Educational Sciences, Malatya.

Akdeniz, A.\& Carikci, E. (2017). Konservatuvar öğrencilerinin "Sanat Eğitimi" kavramına ilişkin metaforik algiları. (Conservatory students' metaphorical perceptions of the concept of "Art Education" ). Mustafa Kemal University Journal of Social Sciences Institute, 14 (40), 59-85. https://dergipark.org.tr/en/download/article-file/394615

Antović, M. (2014). Metaphor about music or metaphor in music: A contribution to the cooperation of cognitive linguistics and cognitive musicology. Metaphors We Study: Contemporary, 233-254. http://dx.doi.org/10.2139/ssrn.2566258.

Aydin, I.S. \& Pehlivan, A. (2010). Türkçe Öğretmeni Adaylarının "Öğretmen" ve "Öğrenci" kavramlarına ilişkin Kullandıkları Metaforlar. (Metaphors Used by Turkish Teacher Candidates on the concepts of "Teacher" and "Student"). Turkish Studies (Electronic) 5(3), 818-842. https://app.trdizin.gov.tr/ publication/ paper/detail/TVRFNE1EQTVPUT09

Barton G. (2018) The Relationship Between Music, Culture, and Society: Meaning in Music. In: Music Learning and Teaching in Culturally and Socially Diverse Contexts in (23-41 ss.). Palgrave Macmillan, Cham. https://doi.org/10.1007/978-3-319-95408-0_2.

Dogan, M. (2020). University students' expectations about the elective music course. Eurasian Journal of Educational Research, 87, 179-198. DOI: 10.14689/ejer.2020.87.9

Ekici, G. \& Akdeniz, H. (2018). Öğretmen adaylarının "sınıfta disiplin sağlamak" kavramına ilişkin algılarının belirlenmesi: Bir Metafor Analizi çalışması.( Determination of pre-service teachers' perceptions about the concept of "providing discipline in the classroom": A Metaphor Analysis study). Dicle University Journal of Ziya Gökalp Education Faculty, 33, 26-37. https://doi.org/10.14582/DUZGEF.1854

Girmen, P. (2007). İlköğretim öğrencilerinin konuşma ve yazma sürecinde metaforlardan yararlanma durumları. (Yayınlanmamış Doktora Tezi). (The use of metaphors by primary school students in the speaking and writing process). (Unpublished Master's Thesis). Anadolu University Institute of Educational Sciences. Eskişehir.

Hicyılmaz, Y.\& Adanır, Y. (2019). Sanat Eğitimi Dersi Alan Öğretmen Adaylarının Sanat Kavramına İlişkin Sahip Oldukları Algıların Metaforlar Aracılığıyla İncelenmesi. ( Examining the Perceptions of Art Education Teachers' Perceptions about the Concept of Art Through Metaphors). Journal of Social Sciences of Mus Alparslan University, 7(3) 9-23. https://doi.org/10.18506/anemon.462012

Ippolitoa, L.M., Nancy J.\& Adlerb, N.J (2018). Shifting metaphors, shifting mindsets: Using music to change the key of conflict. Journal of Business Research, 85, 358-364. https://doi.org/10.1016/j.jbusres.2017.10.013

Cerit, Y. (2008). Öğretmen Kavramı İle İlgili Metaforlara İlişkin Öğrenci, Öğretmen ve Yöneticilerin Görüşleri.( Opinions of Students, Teachers and Administrators Regarding Metaphors Regarding the Concept of Teacher). Journal Of Turkish Educational Sciences, 6(4), 693-712. https://dergipark.org.tr/tr/ download/article-file/256303

Cevik Kılıç, D. B. (2017). Pre-service Music Teachers' Metaphorical Perceptions of the Concept of a Music Teaching Program. Journal of Education and Learning, 6(3), 273-286. http://doi.org/10.5539/jel.v6n3p273. 
Cimen, M.\& Ozevin, B. (2019). Anadolu Lisesi Öğrencilerinin Müzik Kavramı ve Müzik Dersine İlişkin Metafor Algıları. (Anatolian High School Students' Music Concept and Metaphor Perceptions of Music Lesson). UBEST 1 International Symposium on Science, Education, Art and Technology. Full Text Proceedings Book in (1321-1337). https://drive.google.com/file/d/10kzZtk-9IVjXIM8rpO3Q16fBv1ML4XkB/view

Kalyoncu, R. (2013). Sınıf öğretmeni adaylarının "sanat eğitimi dersi" kavramına ilişkin metaforları. (Classroom teacher candidates' metaphors on the concept of "art education lesson" ). Education Sciences, E-Journal of New World Sciences Academy, 8(1), 90-102. https://dergipark.org.tr/tr/download/articlefile/185411

Miles, M.B.\& Huberman, A.M. (1994). Qualitative data analysis: an expanded sourcebook. (2nd Edition). U.S.A: SAGE Publications.

Novak-Leonard, J.\& Skaggs, R. (2017). Public Perceptions of Artists In Communities: A sign of Changing Times. A Journal of Entrepreneurship in the Arts, 6(2), 5-22. https://eds.a.ebscohost.com/ eds/pdfviewer/pdfviewer?vid=15\&sid=0dd3fbe2-eb6e-4b49-bc87-587979e7a306\%40sdc-v-sessmgr02

Pehlivan, A., Aydin, I.S., Kitis, E., \& Ozdemir, E.E. (2019). Metaphoric Perceptions of PreService Teachers Studying in Language Teaching Towards Concept of Writing (Composition), International Online Journal of Educational Sciences, 11 (2), 269-284. https://doi.org/10.15345/iojes.2019.02.018.

Rahman, S.B.B.A., Maaruf, S.Z.\&Rahman, S.B.B.A. (2018). Pre-service Art Teachers' Perception of Multicultural Art Education and Teaching Students from Multicultural Background: An Exploratory Study. Asian Journal of University Education, 14 (1), 89-102. https://eric.ed.gov/?id=EJ1207800

Saban, A., Kocbeker, B. N.\&Saban, A. (2007). Prospective Teachers' Conceptions Of Teaching And Learning Revealed Through Metaphor Analysis. Learning and Instruction, 17, 123-139. https://www.sciencedirect. com/ science/article/pii/S09 59475207000047

Sahin, İ., Zoraloglu, Y.R., \& Firat, N.S. (2011). University Students' Aims in Life, Educational Goals, Expectations from the University and Their State of Satisfaction. Educational Administration: Theory and Practice, 17 (3), 429-452. https://pegem.net/dosyalar/dokuman/127668-2012010417189-sahin.pdf

Schaerlaeken, S., Glowinski, D., Rappaz, M.A.\&Grandjean, D. (2019). "Hearing Music as . . .": Metaphors Evoked by the Sound of Classical Music. Psychomusicology: Music, Mind, and Brain, 29, (2-3), $100-116$. http://dx.doi.org/10.1037/pmu0000233

Yildirim, A. \& Simsek, H. (2011). Sosyal bilimlerde nitel araştırma yöntemleri.( Qualitative research methods in the social sciences ). Ankara: Seçkin Publishing.

Txakartegi, G.I.\& Gomez, M.D. (2008). Metaphors, intercultural perspective and music teacher training at the University of the Basque Country. International Society for Music Education, 26(4), 339-351. [(200811)26:4] 10.1177/0255761408096075. http://ijm.sagepub.com

Umuzdaş, S. \& Umuzdaş, M, S.(2013). Sınıf öğretmenliği öğrencilerinin müzik dersine ilişkin algılarının metaforlar yoluyla belirlenmesi. (Determining primary school students' perceptions of music lesson through metaphors). International Journal of Human Sciences, 10(1), 719-729. https://jhumansciences.com/ ojs/ index.php/ IJHS/article/view/2574/1086

Videira, T. (2011). Describing Music: Perception and Metaphor. The International Journal Of The Arts In Society, 6(4), 255-262.

Wolfe, J. (2019). An investigation into the nature and function of metaphor in advanced music instruction. Research Studies in Music Education, 41(3) 280-292. DOI: 10.1177/1321103X18773113. 
Yalcin Wells, Ş. (2015). Görsel Sanatlar Öğretmeni Adaylarının Öğretmen ve Sanatçı Algısına İlişkin Metafor Analizi. ( Metaphor Analysis of Visual Arts Teacher Candidates' Perception of Teacher and Artist). Hacettepe Üniversitesi Eğitim Fakültesi Dergisi, 30(3). 160-175. http://www.efdergi.hacettepe.edu.tr/ yonetim/icerik/makaleler/673-published.pdf

Tezcan, M. (2018). Sanat Sosyolojisi Giriş. ( Introduction to Sociology of Art). (Extended 3rd Edition). Ankara: Ani Publishing. https://aniyayincilik.com.tr/public/assets/catalogs/0800395001533109475.pdf .

Uygun, M.A.(2015). Öğretmen Adaylarının Geleneksel Müzik Türlerine İlişkin Algılarının Metaforlar Aracilığıyla İncelenmesi. (An Investigation of Pre-Service Teachers' Perceptions of Traditional Music Through Metaphors). Akademik Müzik Araştırmaları Dergisi (AMADER), Journal of Academic Music Research 1(10). 1-16. http://dergipark.gov.tr/amader/issue/1724/21129. DOI NO: 10.5578/AMRJ.8905

\section{Internet References}

Turkish Language Society, https://sozluk.gov.tr/ Access date: 03.02.2020 